\title{
Responsibility and Accountability of University Social and Environmental Performances: A Sustainability Balanced Scorecard Model
}

\author{
Imanda Firmantyas Putri Pertiwi a, Rosana Eri Puspita b, Saifudin c \\ $a, b, c$ Faculty of Islamic Economics and Business, IAIN Salatiga, Indonesia \\ Corresponding email: imanda.putri@iainsalatiga.ac.id \\ doi http://dx.doi.org/10.22515/shirkah.v1i1.343
}

\begin{tabular}{|c|c|}
\hline ARTICLE INFO & ABSTRACT \\
\hline $\begin{array}{l}\text { Keywords: } \\
\text { Responsibility and } \\
\text { Accountability; Social and } \\
\text { Environmental Performances; } \\
\text { Sustainability Balanced } \\
\text { Scorecard } \\
\text { Article history: } \\
\text { Received: } 01 \text { October } 2020 \\
\text { Revised: } 17 \text { February } 2021 \\
\text { Accepted: } 18 \text { February } 2021 \\
\text { Available online: } 09 \text { March } 2021 \\
\text { To cite in APA style: } \\
\text { Pertiwi, I. F. P., Puspita, R. E., \& } \\
\text { Saifudin. (2021). Responsibility } \\
\text { and Accountability of } \\
\text { University Social and } \\
\text { Environmental Performances: A } \\
\text { Sustainability Balanced } \\
\text { Scorecard. Shirkah: Journal of } \\
\text { Economics and Business, 6(1), 1-17 }\end{array}$ & $\begin{array}{l}\text { Since research on the use of sustainability balanced scorecard to } \\
\text { assess university social and environmental performances still } \\
\text { remains unexplored, this study aims to fill the gap by examining } \\
\text { the acceptance of the idea of the State Islamic Religious Colleges } \\
\text { (PTKIN) performances in terms of responsibility for social and } \\
\text { environmental aspects based on the sustainability balanced } \\
\text { scorecard model. Drawing on a qualitative research, eight } \\
\text { respondents from the Board of National Accreditation for Higher } \\
\text { Education (BAN-PT) and PTKIN policymakers were } \\
\text { interviewed. The results indicated that PTKIN must pay more } \\
\text { attention to social and environmental perspectives. It was further } \\
\text { revealed that although BAN-PT regulation has explicitly } \\
\text { included these two perspectives, there were several indicators } \\
\text { that still need to be added according to the sustainability } \\
\text { balanced scorecard model. Moreover, the results depicted } \\
\text { several challenges such as budgeting, regulations, and } \\
\text { paradigms that required some adjustments from the } \\
\text { policymakers. These results contribute as fruitful insights for } \\
\text { university policymakers in developing strategies to enhance } \\
\text { university performances, particularly in social and } \\
\text { environmental aspects. }\end{array}$ \\
\hline
\end{tabular}

This work is licensed under a Creative Commons Attribution-NonCommercial 4.0 International License.

\section{Introduction}

Companies in running their business are not only paying attention to short-term goals but also long-term goals, and one of the long-term goals of a company is to create sustainability. Many researchers have modeled the concept of assessing sustainable company performance. Some of them are balanced scorecard (Kaplan \& Norton, 1992), sustainability balanced scorecard (Figge et al., 2002), corporate social responsibility (Bowen, 1953), triple bottom line (Elkington, 1998), global initiatives reporting (Global Reporting Initiatives, 2006), and the prism model (Neely et al., 2002). All of the above 
models have the same principle; if the company wants its business to be sustainable, then the interests of the stakeholders both internal and external must be covered.

From the above performance measurement models, the balanced scorecard is a model that, according to Harvard Business Review, has had the most significant influence in this decade (Betianu \& Briciu, 2011). However, Kaplan and Norton's idea to combine financial and non-financial aspects in the formulation of corporate strategy still needs to be added with the elements of sustainability. Figge et al. (2002) initiated a model called Sustainability Balanced Scorecard (SBSC). While Kaplan and Norton's BSC has four perspectives in assessing company performance (finance, customers, internal processes, and learning and development), SBSC adds additional perspectives that are considered to represent sustainability; social and environmental perspectives.

Theories in social and environmental perspectives have been discussed by several experts (Beschorner, 2013; Brammer et al., 2012; Branco \& Rodrigues, 2006; Du et al., 2017; Marín \& de Maya, 2013; McWilliams \& Siegel, 2011; Sen \& Cowley, 2013). Legitimacy, stakeholder, and institutional are three mainstream theories that are used to explain the importance of companies paying attention to their social responsibilities (Fernando \& Lawrence, 2014). A single theory is not enough to be a theoretical framework to explain the Corporate Social Responsibilities (CSR) behavior of an organization (Fernando \& Lawrence, 2014). Each thesis will have its advantages and disadvantages. As stated by Clifton \& Amran (2011), the Stakeholders Approach (SHA), as viewed through a sustainability lens, is still incomplete to be considered as helping policymakers in carrying out their corporate sustainability obligations. Legitimacy theory can explain CSR well if it is done transparently and with full honesty, but it will have the opposite effect if the transparency and honesty process is ignored (Du \& Vieira, 2012). Thus, in addition to these three general theories, resource-based theory, sharedvalue theory, consumer-company identification theory, and social capital theory are alternative theories that also support the importance of social and environmental aspects for the sustainability of a company or organization.

University, as an organization, must also pay attention to its performances. As one of the models to measure sustainable strategies of an organization, Sustainability Balanced Scorecard (SBSC) emphasizes on environmental and social aspects (Figge et al., 2002). Studies on SBSC have revealed four perspectives of 'conventional' Balanced Scorecard by adding one new perspective; a combination of social and environmental aspects (Alewine \& Stone, 2013), which is then divided into two perspectives with different scorecards in this study according to the third scenario of courtesy of Kalender \& Vayvay (2016). Research on how to assess higher education performance using the balanced scorecard method has been carried out both by many researchers (Lestari, 2013; Sudaryo, 2015; Soegoto, 2011; Mahmudi et al., 2014; Antariksa \& Setiawan, 2014; AlAshaab et.al., 2011; Zangoueinezhad \& Moshabaki, 2011). However, there has not been a single study that uses sustainability balanced scorecard in assessing university 
performances. Whereas, it is undeniable that social and environmental perspectives are essential issues that should be considered by university as a higher education organization.

So far, university performances have been assessed under the control of the Board of National Accreditation for Higher Education (BAN-PT) using nine criteria, i.e. (1) Vision, Mission, Goals, and Strategies; (2) Governance and Cooperation; (3) Students; (4) Human Resources; (5) Finance, Facilities and Infrastructure; (6) Education; (7) Research; (8) Community Service; and (9) Tridharma Outcomes (Asy'ari, 2015). Through its nine criteria, BAN-PT tries to assess and ensure that universities have conducted their operational based on standard. On the perspective of sustainability balanced scorecard theory, an organization is assessed if its performance depends on financial or nonfinancial sources. Research has indicated that an organization's transparency and accountability are seen not only by financial statements but also by social responsibility (Ahmad et al., 2018; Andraeny \& Putri, 2017); as a result, many organizations use their social accountability reports as a way to improve their credibility and preserve its reputation (Sidik \& Reskino, 2016). Hence, this study aims to explore the possible synchronization between BAN-PT policy and the theory of sustainability balanced scorecard. The theory of the SBSC illustrates the urgency of measuring organizational efficiency as seen from social and environmental dimensions (Jassem, Zakaria, \& Azmi, 2021), and this study is directed to further investigate whether these two aspects have been integrated in the BAN-PT policy.

From the nine criteria formulated by BAN-PT, and when they are related to the concept of sustainability balanced scorecard, environment is the only aspect that has not been taken into account. Therefore, the primary objective, which can be a novelty of this study, is examining if the idea of measuring university performances based on sustainability balanced scorecard by considering social and environmental aspects for State Islamic Religious Colleges (PTKIN) is acceptable. By involving policymakers in PTKIN and BAN-PT, the results of this study contribute as fruitful insights for university policymakers in developing strategies to enhance university performances, particularly in social and environmental aspects.

\section{Method}

\section{Research Design}

This study aims to examine the potential use of SBSC-based standard to measure State Islamic Religious Colleges (PTKIN) performances in terms of social and environmental perspectives. This study explore the six core themes with regards to the two aspects, i.e. (1) the importance of social and environmental perspectives in measuring higher education performance; (2) BAN-PT regulations containing social and environmental aspects; (3) indicators of social perspective; (4) indicators of environmental perspective; (5) regulation of social and environmental perspectives; and (6) higher education readiness to adopt social and environmental perspectives. To reach the objective, an 
exploratory qualitative research was adopted to delineate the phenomenon being studied. In the context of this study, the qualitative research was employed to scrutinize the participants' ideas, views, and perceptions about the integration of social and environmental aspects to assess the universities performances based on the model of sustainability balanced scorecard.

\section{Sample Selection and Data Sources}

This study involved two respondents who had a background as BAN-PT assessors, on the reasons that they have definitely mastered any indicators in higher education performance appraisals and are able to give their opinion on whether social and environmental perspectives are reliable to be included as key performance index assessment of university performances. In addition, this study also interviewed six policymakers of Islamic State Religious Colleges (PTKIN) with the aim of understanding the readiness of universities if social and environmental perspectives are adopted as criteria for university performance assessment. The university policymakers involved in this study represented several campus authorities such as rectors, vice rectors, dean, head of study programs, quality assurance unit, and research and community services. The description of the respondents is presented in table 1.

Table 1. Respondent Information Table

\begin{tabular}{llcl}
\hline $\begin{array}{l}\text { Respondent } \\
\text { Code }\end{array}$ & Respondent Category & $\begin{array}{l}\text { Number of } \\
\text { Respondents }\end{array}$ & Interview Technique \\
\hline BAN 01-02 & BAN-PT Assessor & 2 & $\begin{array}{l}\text { Telephone } \\
\text { Telephone }\end{array}$ \\
REK 01 & $\begin{array}{l}\text { Policy Makers of } \\
\text { Rectorate Level }\end{array}$ & 1 & Telephone \\
DEK 01 & $\begin{array}{l}\text { Policy Makers of Dean } \\
\text { Level }\end{array}$ & 1 & PRO 01 WA \\
PRO 01-02 & $\begin{array}{l}\text { Policy Makers of Study } \\
\text { Program Level }\end{array}$ & 2 & $\begin{array}{l}\text { PRO 02 Offline } \\
\text { LEM 01-02 }\end{array}$ \\
& LPM/LP2M 01 WA \\
& Total & 2 & LEM 02 Offline \\
\hline
\end{tabular}

\section{Instrumentation and Data Collection}

This study followed the steps taken by Rabionet (2011) in conducting qualitative interviews as follows: (1) selecting the type of interview; (2) developing ethical guidelines; (3) developing interview protocols; (4) conducting and recording interviews; (5) analyzing and concluding the results of the interview; and (6) reporting the findings. A total of eight respondents involved in this study and were interviewed from 13 to 20 April 2020 (see table 2). The interviews were planned to be carried out online (video call 
or telephone), due to the Covid 19 pandemic. Research permission was submitted to each respondent before the interview began. Several respondents wanted to be interviewed face-to-face with the reason to gain a better understanding of the research context (PR 02 and LEM 02), so offline techniques were still carried out. Some respondents wanted interviews to be conducted via text by means of WhatsApp for reasons of convenience (PR 01) and the time that did not match for video calls or telephone calls (LEM 01).

Table 2. Interview Duration

\begin{tabular}{lll}
\hline Respondent & Time & Duration \\
\hline BAN 01 & 14 April 2020 19.28 & 38.50 minutes \\
BAN 02 & 15 April 2020 17.16 & 19.41 minutes \\
REK 01 & 15 April 2020 19.09 & 26.51 minutes \\
DEK 01 & 20 April 2020 10.15 & 33.01 minutes \\
PRO 01 & 14 April 2020 15.43 & 2 hours 23 minutes \\
PRO 02 & 20 April 2020 13.20 & 1 hours 10 minutes \\
LEM 01 & 20 April 2020 09.00 & 35 minutes \\
LEM 02 & 14 April 2020 17.01 & 44 minutes \\
\hline
\end{tabular}

\section{Data Analysis}

The data analysis in this study was conducted manually without using a particular coding software. First, the procedural steps of data analysis process was begun with identifying and coding the research categories in which the respondents' opinions, ideas, and views were explored to examine the similar themes between one respondent and others, as well as themes that were contradicting to the majority opinion. Second, mapping the relationship among the answers was conducted to ensure that the researchers did not waste the time on useless questions that were not closely related to the issues of this study. Third, tabulating the number of responses in the form of percentage of respondents' profile and percentage of their answers. The last, building an in-depth understanding about the emerging themes with regards to the answers of the research question and related them to previous literature (Vaughn \& Turner, 2016).

\section{Results}

\section{Crucial Roles of Social and Environmental Perpectives}

Higher education is required to make a real contribution to solving social problems that exist in society to create a sustainable future (Wijaya \& Krismiyati, 2016). This opinion was agreed upon by all respondents (BAN 01-02, REK 01, DEK 01, PRO 01-02, LEM 0102). The reason given by all respondents could be considered similar. If a university does not pay attention to the social aspect, it will become an ivory tower (PRO 02) that cannot exist (BAN 02) because it is abandoned by the market (DEK 01). Social care is a form of social and emotional intelligence (REK 01) and a form of reciprocation due to the 
existence of higher education, one of which comes from community support (LEM 01). On behalf of the third higher education Tridharma, community service as the reflection of the social elements carried out by higher education is the most substantial reason for universities not to ignore social and environmental aspects (BAN 01 and PRO 01). As several respondents said:

"If we talk about social and environmental aspects, then we will talk not only about the internal environment but also the external environment of the organization. The internal environment of higher education consists of students, lecturers, employees and the academic community on campus and everything that supports campus activities, especially the tridharma of higher education. The priority of the internal environment of higher education is to improve the quality of tridharma. Meanwhile, the external environment is expected to provide input, criticism, and suggestions for improving the internal environment and as a quality supervisor of the internal environment. The social aspect is important because through this aspect, universities can connect with various parties, both internal and external, to achieve the goals of higher education. The Balance Scorecard consists of 4 perspectives, namely: financial, customer satisfaction, growth and learning and internal business processes, I think adding a social and environmental perspective is a very good idea" (PRO 01).

\section{BAN-PT Regulations on Social and Environmental Perspectives}

BAN-PT regulation Number 2 Year 2019 has determined the university accreditation system through nine criteria. Based on the nine existing criteria, it turns out that social and environmental perspectives have been involved in it according to all respondents (BAN 01-02, REK 01, DEK 01, PRO 01-02, LEM 01-02). On average, almost all respondents answered that the standards/criteria that discuss community service, in this case, are eight criteria (for an accreditation system of 9 criteria) or seventh standard (for an accreditation system of 7 standards) are matters that have specifically discussed social perspective (BAN 01-02, REK 01, DEK 01, PRO 01, LEM 01-02).

In addition to the seventh standard or the eighth criterion, in the fifth standard regarding intellectual behavior, social aspects also exist. Scholarly action is the ability to respond and provide solutions to community and environmental problems (University of Muhammadiyah Surabaya, 2014). Community service and the development of intellectual behavior are two instruments that include implicit social aspects; however, we can also find this aspect explicitly in other standards/criteria. Social care, indicated by user involvement in several things, for example, curriculum preparation (LEM 01, LEM 02, REK 01, DEK 01), and the preparation of a vision and mission (REK 01), shows that higher education has paid attention to the interests of their stakeholders.

The respondents discussed that the second criteria/standard regarding the civil service system also contained a social aspect. Governance system is a system that guarantees the realization of the vision, the implementation of the mission, the 
achievement of goals, and the success of the strategies used in a credible, transparent, accountable, responsible and fair manner (Universitas Muhammadiyah Surabaya, 2014). The point is that in every BAN-PT accreditation standard/criteria, these social and environmental elements have been involved. As one of the respondents said:

"When viewed from the tri dharma, BAN-PT assesses the social environment from all aspects, for example, from the teaching point of view, BAN-PT will see whether the curriculum is following the demands. In terms of research, the themes offered to lecturers always pay attention to social aspects, usefulness. For social and community, whether it has been considered. Then for community service, especially yes, universities have been consistent in carrying out community service in the form of KKN" (DEK-01).

\section{Social Perspective Indicators}

The social perspective described by the respondents is already listed in the regulations or has been implemented through higher education activities, both incidental and permanent. One of the higher education activities that are carried out permanently related to this social aspect is Community Service Program (Kuliah Kerja Nyata). In creating, instilling, enhancing, and maintaining a positive corporate image, companies can carry out soft marketing through social activities (Yulianita, 2008). Higher Education Social Responsibility (HESR) carried out by universities is proven to increase the ability of universities to intake and obtain qualified students (Harjanto, 2019; Wijaya \& Krismiyati, 2016).

So, it is undeniable that social activities are carried out not only as a form of corporate responsibility but also as a means of soft marketing for image creation. In addition, applying the principle of participatory stakeholders, contributing thoughts, ideology, literacy, economic improvement, and self-development are also activities that can be classified into a social perspective. Hence, social activities are not always interpreted by respondents as activities that are philanthropic because the indicators of social responsibility for higher education are various, consisting of economic responsibility, legal responsibility, ethical responsibility, and philanthropic responsibility (Atiqah, 2019). PTKIN is higher education institutions with an Islamic identity and prioritizes its activities related to Islamic matters. Likewise, when PTKIN carries out activities that are socially oriented, it prioritizes those with Islamic values.

It seems that the social aspect has indeed been considered an important aspect of higher education assessment. It was agreed upon by all respondents, both BAN-PT assessors, university policymakers at the rectorate level, at the faculty level, at the study program level, and also the units. However, there are still some obstacles. One of the main constraints is the budget (BAN 01, BAN 02, PRO 01, LEM 02). As one of the respondents said: 
“... But unfortunately, social and environmental activities are incidental only for certain interests, for example, just to fulfill ISO or accreditation elements so that their implementation has not been effective. But hopefully, in the future, activities related to social and environmental aspects can really be carried out optimally" (PRO 01).

\section{Environmental Perspective Indicators}

The government and universities have started to be aware of environmental issues (BAN 01) and realized that a healthy, green, and beautiful environment is one of the factors supporting a good academic atmosphere (REK 01). PTKIN in Indonesia needs to go after UIN Radin Intan Lampung for the issue of a sustainable green campus (BAN 02). The National Green Campus Workshop at UIN Radin Intan Lampung from 14-16 August, which was attended by PTKIN chancellors throughout all over Indonesia, discussed the importance of the concept and practice of a sustainable university (Abdullah, 2019).

University of Indonesia (UI) initiated a metric called the UI Green Metric to rank universities with a green and sustainable environment. The purpose of making this metric is to invite university leaders and stakeholders to care about global climate change, energy and water conservation, waste recycling, and green transportation. Several indicators of a green campus are (1) the ratio of open space to the total area of a university; (2) the area covered by forest; (3) the area covered with plants; (4) the area used for water absorption; (5) the total area of open space compared to the entire campus area; and (6) the budget for sustainability efforts (UI, 2020).

According to respondents, the existence of a workshop on a sustainable university in Lampung and the existence of the UI Green Metric was able to make PTKIN leaders move towards creating a green and sustainable campus. Several efforts have been made. Expanding open space, allocating areas for water absorption, increasing the sum of trees, and plants. In the context of environmental management, it is appropriate for universities to carry out synergies between scientific disciplines and no longer think facultative. This synergy is not only carried out at the internal university level but must also involve the government, community, community organizations, professionals, and all elements that can support it. As one of the respondent said:

"In the world of education, there are three fields of facultative science. The first is a natural science, second is a social science, and last is the humanities. Natural science means going to technical aspects. For example, the Central Java government is actively implementing a waste management program. Start from composting to crafting. Now, natural science can act on the technical aspects of waste management. In contrast, social science can develop its socialization through out-of-school education. Simultaneously, the humanities faculty can play a role in shaping a philosophical way of thinking to the community regarding waste management. Unfortunately, when the government is active in implementing this program, it doesn't seem to be accompanied by cooperation with universities as consultants. I had a long discussion with the deputy regent of Central Java about the program to turn garbage 
into flies, then fly into animal feed. So that indeed, there must be a collaboration between stakeholders and facultative. Local governments will not be strong enough to manage this issue on their own" (BAN 01).

Although PTKIN's efforts to carry out its waste management have been running quite well, there are still many obstacles and there is a lot of work to be done for policymakers at the central level such as the ministry and BAN-PT to solve. Some of the perceived obstacles are that there is still a mixture of budgets for reforestation and maintenance so that this budget is often eroded for other interests (REK 01) so that later some universities even make the issue of environmental management a mere formality and get the last priority, the majority of its implementation still incidental (BAN 01, BAN 02, PRO 01, PRO 02). As one of the respondents said:

".... There are several universities that have declared themselves as green campuses, such as UNNES. PTKIN has also launched a green campus, which was inaugurated in Lampung and attended by all the chancellors. Departing from the meeting in Lampung, a program of assistance from the province appeared and others for planting a thousand trees and so on. Meanwhile, with regard to waste, I think every university has its own waste treatment system, whether traditional or modern, starting as simple as a septic tank. In essence, the seeds for concern about the environment are already in the university environment." (PRO 02)

\section{Social and Environmental Perspective Regulations}

According to Suhardiyah \& Nurdina (2019), several stages must be carried out by universities in implementing Green Accounting-University Social Responsibility (GRUSR). These stages are (1) Social-Environmental Awareness; (2) Social-Environmental Engagement; (3) Social-Environmental Reporting; and (4) Social-Environmental Audit. The first two stages, building socio-environmental awareness and implementing socioenvironmental activities, have been carried out well even though there are still some shortcomings and obstacles faced by universities. The next stage is to ensure that activities are appropriately reported and audited.

The nine criteria of BAN-PT regulations are considered by some respondents as sufficient to encourage higher education to carry out their social and environmental responsibilities (LEM 01, LEM 01). However, several other respondents responded slightly differently, although they agreed that in the nine criteria for BAN-PT social and environmental aspects had been discussed, several things needed to be added (REK 01, BAN 01, BAN 02, PRO 01, DEK 01). Some of the respondents said:

"In my opinion, BAN-PT must be more firm in determining that there must be a greening budget of a certain percentage. Or there must be a certain percentage of campus parks. So it's not specific. We haven't talked about waste and other things ... " (REK 01).

"... the hope is that there is a paradigm shift ..." (BAN 01). 
“... The nine criteria already contain social and environmental aspects, especially if the tertiary institution wants to achieve Unggul (superior) standards. Still, when the tertiary institution meets the requirements under UNGGUL, then international certifications will be ignored, even though it is in fulfilling those certifications. In fact, the social and environmental aspects are widely discussed" (TIRE 02).

"In my opinion, it is appropriate for BAN-PT to make its own separate criteria specifically discussing social and environmental issues so that these two aspects are really considered and not become a formality or incidental activities only ..." (PRO 01).

"In my opinion, it is necessary to make specific rules in the strategic plan and the operational plan documents and so that we have a foundation to carry out these activities so that they can become a shared insight about an environmentally friendly campus. For example, ensuring that you have a certain percentage of land for green land, in my opinion, a special regulation needs to be given..." (DEK 01).

\section{University Readiness to Adopt Social and Environmental Perspectives}

The readiness of higher education institutions to treat social and environmental aspects optimally is the central aspect in evaluating their performances. Higher education must collaborate with various parties to optimally adapt the two aspects. Social activities that connect directly between the campus and the community must be assisted by professionals in their fields. Universities must be able to move theory to practice, and from practice back to theory, to make the theory more relevant and realistic (Symaco \& Tee, 2019). This opinion of Symaco \& Tee (2019) is in line with the opinion of BAN 01, BAN 02, and LEM 01. The gradual and long process that PTKIN must undertake in order to be able to fully adopt social and environmental aspects is recognized by the policymakers of the tertiary institutions and the assessors of BAN-PT.

"... Although there is still a long way to go, universities must be ready to adopt it. And it must be a priority. I really support your research. This is very good for us to convey to the policymakers at the center there" (REK 01).

"... PTKIN, inshaAllah, is ready, especially considering the capabilities of the lecturers at IAIN Salatiga" (LEM 01).

\section{Discussion}

The results of previous studies (Cahya et al., 2019; Suhardiyah \& Nurdina, 2019; Harjanto, 2019; Mustika \& Sahudra, 2018; Asy'ari, 2015; Wijaya \& Krismiyati, 2016; Rumambi \& Lintong, 2017; Symaco \& Tee, 2019; Atiqah, 2019) regarding to the importance of social and environmental aspects for higher education were agreed by the answers of all the respondents in this study. They all consider that social and environmental aspects are crucial for higher education to pay attention to and measure its performance.

So, what do the findings of this study imply for us? BAN-PT, an institution that 
assesses the performance of higher education, issues a regulation that contains what instruments a higher education must comply within its performance. This study aims to map whether the social and environmental aspects are included in the instruments assessed by BAN-PT. The answers from the respondents were also almost similar that in the regulation of the Board of National Accreditation for Higher Education (BAN-PT) Number 2 Year 2017, it was determined the nine criteria that became accreditation instrument and The instrument of seven standards according to the Guidebook for Filling Accreditation Forms compiled by BAN-PT have included social and environmental aspects. These aspects can be seen in the eighth criteria/seventh standard regarding community service; on the fifth standard of intellectual behavior; on second standard/criteria regarding the guidance system; in the first standards and also fifth standards concerning user involvement in both the preparation of the vision and mission and the curriculum, and even in each standard or criteria, social and environmental aspects are also discussed.

The social perspective described by the respondents is already listed in regulations or has been implemented through university activities. However, in its implementation, several deficiencies must be corrected in the future. The variety of social actions, according to the concept promoted by (Kotler \& Lee, 2005) and (Atiqah, 2019) can take various forms including (1) applying the principle of participatory stakeholders by involving users in the formation of a vision, mission, and curriculum; (2) contributing thoughts, ideology, literacy, economic improvement, and self-development; (3) Islamic ideological responsibility, through the implementation of the Ramadhan safari, a curriculum containing Islam moderate, meetings of community and religious leaders and preaching through Qurban to the surrounding community; and (4) philanthropic responsibility.

A part from those activities, there is a social program that is consistently carried out by PTKIN every year and is considered very effective in bringing the campus closer to the community, namely Community Service Programs (Kuliah Kerja Nyata). However, even though higher education with various activities have carried out the social aspect, several obstacles are still found, some of them are (1) budget; (2) the portion that seems to be the smallest among the other tri dharma of higher education; and (3) many of them are incidental and only become a formality. Likewise, with regards to environmental aspects, several obstacles are also found, some of them are (1) the awareness of the academic community is still minimal; (2) making this environmental issue the last concern when compared to the other components of the tri dharma; (3) budget; (4) PTKIN yet does not have many general study programs that have knowledge related to the environment; and (5) regulations for PTKIN that focus on environmental issues will only be seen when the PTKIN concerned tries to meet the UNGGUL criteria, and not yet 
half of the total PTKIN in Indonesia has reached the UNGGUL criteria.

However, it does not mean that PTKIN does not strive towards a green and sustainable campus. Some of the activities related to the sustainability of the campus that have been carried out by PTKIN are as follows: (1) reforestation by planting tall green plants and gardening to create a green campus; (2) fostering the environment around the campus by conducting road planning and having consultation related to health and sanitation; (3) constructing facilities and infrastructure that support campus health, such as biological gardens, sports facilities, pedestrians, water storage lakes; bio-pori, water absorption wells; (4) waste management; and (5) efforts to be paperless. Work Plan and Budget of Ministries/State Institutions, the implementation of each activity must go through bureaucratic steps to ensure accountability. Since one of these social and environmental activity goal is to increase the intake of the university, there is nothing wrong if these activities are also published on the web, social media, mass media, and campus magazines.

According to some respondents, the regulations stipulated by BAN-PT with nine criteria are sufficient to accommodate social and environmental aspects, so adding new rules or new formats seems not necessary. Additional rules that focus on social and environmental aspects are not needed at the BAN-PT level. Still, at the internal level, the priority must be increased and written down in the strategic planning and operational planning of higher education is needed. However, according to several other respondents, the focus on social and environmental aspects could be improved by slightly changing or adding to existing regulations. Respondents agreed that BAN-PT in its regulations should be focused on social and environmental aspects, and added a different criterion in which specifically discussing social and environmental aspects is an interesting idea. It is unnecessary to add a separate criterion, but at least the budget and portion for social and environmental aspects must be increased at least equal to the amount of teaching and research activities.

PTKIN, with all its resources, is ready to increase its focus on social and environmental aspects. Matters that are still considered to be obstacles, such as budgets and regulations, must gradually be overcome, one of which is to collaborate with various parties such as the central and local governments, experts, or professionals in the fields needed, community organizations, religious leaders and the surrounding community.

Overall, this research contributes to the point of views of policymakers, both for BAN-PT and for universities. This research explains that although social and environmental aspects have been accommodated in the policies made by BAN-PT, these aspects have not become the main focus. While this research shows that these two factors are very important in supporting other performance factors, including financial 
performance, because these social and environmental aspects, although they are costs in the short term, will be an investment to achieve the long term sustainability of universities.

\section{Conclusion}

This study indicates that to fulfill the interests of all stakeholders under the sustainability balanced scorecard (SBSC) model developed by Figge et al. (2002), universities have attempted to fulfill the standard based on BAN-PT regulations regarding to the accreditation instruments. Based on interviews conducted with eight respondents consisting of two BAN-PT assessors, one policymaker in the rectorate level, one policymaker in the faculty level, two policymakers in the study program level, and the other two from higher education units. It can be concluded that social and environmental perspectives have not been formulated separately in a different criteria/standard. The result of this study contribute as fruitful insights for university policymakers in developing strategies to enhance university performances, particularly in social and environmental aspects. Apart from the comprehensive results, this study acknowledges several limitations. First, the analysis in this study is only carried out from a social and environmental perspective, while the other four perspectives in SBSC have not been discussed yet. Second, the subjects in the study are limited to the assessors from BANPT and higher education policymakers, while SBSC has the concept of fulfilling the interests of all stakeholders. Therefore, it is hoped that further research examines all perspectives in SBSC by confirming all stakeholders who are considered competent to provide their opinions to enhance the university performances.

\section{Authors' Declaration}

The authors made substantial contributions to the conception and design of the study. The authors took responsibility for data analysis, interpretation and discussion of results. The authors read and approved the final manuscript.

\section{Acknowledgement}

This research was funded by a research grant program from the Ministry of Religious Affairs of Republic of Indonesia.

\section{References}

Abdullah, M. (2019). UIN Raden Intan Lampung dan Gerakan Konservasi Lingkungan di PTKIN - Green Campus UIN Lampung. Accessed in August 2020 from https://green.radenintan.ac.id/uin-raden-intan-lampung-dan-gerakan-konservasilingkungan-di-ptkin/

Ahmad, K., Othman, K., Zabri, S. M., \& Yaakub, A. A. (2018). Factors Associated with the SMEs Preferences Towards Islamic Banking Products and Services. Advanced 
Science Letters, 24(6), 4726-4730. https://doi.org/10.1166/asl.2018.11689

Al-Ashaab, A., Flores, M., Doultsinou, A., \& Magyar, A. (2011). A balanced scorecard for measuring the impact of industry-university collaboration. Production Planning and Control, 22(6), 554-570. https://doi.org/10.1080/09537287.2010.536626

Alewine, H. C., \& Stone, D. N. (2013). How does environmental accounting information influence attention and investment? International Journal of Accounting and Information Management, 21(1), 22-52. https://doi.org/10.1108/18347641311299731

Andraeny, D., \& Putri, D. D. (2017). Islamicity Financial Performance Index in Indonesian Islamic Banks. Shirkah: Journal of Economics and Business, 2(3), 317-253. https://doi.org/10.22515/shirkah.v2i3.170

Antariksa, W. F., \& Setiawan, M. (2014). Pengaruh penerapan sistem manajemen mutu ISO 9001: 2008 di perguruan tinggi terhadap kinerja balanced scorecard (Studi Kasus pada Universitas Brawijaya). Jurnal Aplikasi Manajemen, 12(3), 399-406.

Asy'ari, H. (2015). Perbandingan Sistem Manajemen Mutu ISO 9001:2008, Standard BANPT dan Total Quality Management di UIN Maulana Malik Ibrahim Malang. Jurnal Pendidikan Islam, 4(1), 141-157. https://doi.org/10.14421/jpi.2015.41.141-157

Atiqah, A. (2019). Tanggung Jawab Sosial Universitas dan Tata Kelola Universitas Terhadap Citra UIN Syarif Hidayatullah Jakarta. Akuntabilitas, 12(2), 169-178. https://doi.org/10.15408/akt.v12i2.

Beschorner, T. (2013). Creating Shared Value: The One-Trick Pony Approach. Business Ethics Journal Review, 1(17), 106-112. https://doi.org/10.12747/bejr2013.01.17

Betianu, L., \& Briciu, S. (2011). Balanced scorecard - sustainable development tool. Analele Ştiinţifice Ale Universităţii »Alexandru Ioan Cuza«Din Iaşi. Ştiinţe Economice, 58(Spec), 19-27.

Bowen, H. R. (1953). Social Responsibilities of the Businessman. Iowa: University of Iowa Press.

Brammer, S., Jackson, G., \& Matten, D. (2012). Corporate social responsibility and institutional theory: New perspectives on private governance. Socio-Economic Review, 10(1), 3-28. https://doi.org/10.1093/ser/mwr030

Branco, M. C., \& Rodrigues, L. L. (2006). Corporate social responsibility and resourcebased perspectives. Journal of Business Ethics, 69(2), 111-132. https://doi.org/10.1007/s10551-006-9071-z

Du, S., Yu, K., Bhattacharya, C. B., \& Sen, S. (2017). The Business Case for Sustainability Reporting: Evidence from Stock Market Reactions. Journal of Public Policy and Marketing, 36(2), 312-330.

Elkington, J. (1998). Partnerships from cannibals with forks: The triple bottom line of 21st-century business. Environmental quality management, 8(1), 37-51. 
Figge, F., Hahn, T., Schaltegger, S., \& Wagner, M. (2002). The sustainability balanced scorecard - Linking sustainability management to business strategy. Business Strategy and the Environment, 11(5), 269-284. https://doi.org/10.1002/bse.339

Global Reporting Initiatives. (2006). Global Reporting Initiative Global Reporting Initiative( GRI ) Uptake.

Harjanto, N. (2019). Implementation Strategy of Higher Education Social Responsibility to Acquire New and Qualified In-Line Students : A Case Study. Indonesian Journal of Sustainability Accounting and Management, 3(2), 162-173. https://doi.org/10.28992/ijsam.v3i2.93

Jassem, S., Zakaria, Z., \& Azmi, A. C. (2021). Sustainability balanced scorecard architecture and environmental performance outcomes: a systematic review. Productivity and Performance Management. https://doi.org/10.1108/IJPPM-12-20190582

Kalender, Z. T., \& Vayvay, Ö. (2016). The Fifth Pillar of the Balanced Scorecard: Sustainability. Procedia - Social and Behavioral Sciences, 235(October), 76-83. https://doi.org/10.1016/j.sbspro.2016.11.027

Kaplan, R. S., \& Norton, D. P. (1992). The Balanced Scorecard-Measures that Drive Performance. Harvard Business Review, 83(7), 172

Kotler, P., \& Lee, N. (2005). Best of breed: When it comes to gaining a market edge while supporting a social cause, "corporate social marketing" leads the pack. Social Marketing Quarterly, 11(4), 91-103. https://doi.org/10.1080/15245000500414480

Lestari, A. S. (2013). Analisis Penilaian Kinerja Lembaga Pendidikan Tinggi Dengan Metode Balanced Scorecard: Penerapannya Dalam Sistem Manajemen Strategis (Studi Kasus Pada Universitas Brawijaya Malang). 2nd International Seminar on Quality and Afforable Education, 52(April), 441-450.

Mahmudi, A. A., Surarso, B., \& Subagio, A. (2014). Kombinasi Balanced Scorecard dan Objective Matrix Untuk Penilaian Kinerja Perguruan Tinggi. Jurnal Sistem Informasi Bisnis, 4(1), 1-10. https://doi.org/10.21456/vol4iss1pp01-10

Marín, L., \& de Maya, S. R. (2013). The role of affiliation, attractiveness and personal connection in consumer-company identification. European Journal of Marketing, 47(3), 655-673. https://doi.org/10.1108/03090561311297526

McWilliams, A., \& Siegel, D. S. (2011). Creating and capturing value: Strategic corporate social responsibility, resource-based theory, and sustainable competitive advantage. Journal of Management, 37(5), 1480-1495. https://doi.org/10.1177/0149206310385696

Neely, A. D., Adams, C., \& Kennerley, M. (2002). The performance prism: The scorecard for measuring and managing business success. London: Prentice Hall Financial Times.

Rabionet, S. E. (2011). How I Learned to Design and Conduct Semi-structured 
Interviews: An Ongoing and Continuous Journey. The Qualitative Report, 16(2), 563-566.

Sen, S., \& Cowley, J. (2013). The Relevance of Stakeholder Theory and Social Capital Theory in the Context of CSR in SMEs: An Australian Perspective. Journal of Business Ethics, 118(2), 413-427. https://doi.org/10.1007/s10551-012-1598-6

Sidik, I., \& Reskino, R. (2016). Zakat and Islamic Corporate Social Responsibility: Does It

Take Effect to the Performance of Shari'a Banking?. Shirkah: Journal of Economics and Business, 1(2), 161-184. doi:http://dx.doi.org/10.22515/shirkah.v1i2.23

Soegoto, E. S. (2011). Penerapan Manajemen Kinerja dengan Pendekatan Balanced Scorecard dalam Meningkatkan Akuntabilitas Pengelolaan Perguruan Tinggi. Majalah Ilmiah Unikom, 6(2), 131-142.

Sudaryo, Y. (2015). Kinerja Perguruan Tinggi dengan Pendekatan Strategic Map Balanced Scorecard. Sosiohumaniora, 17(1), 1-12.

Suhardiyah, M., \& Nurdina. (2019). Implementation of environmental accounting in higher education solutions to improve the college's role in the implementation of corporate social responsibility. IOP Conference Series: Earth and Environmental Science, 245(1). https://doi.org/10.1088/1755-1315/245/1/012027

Symaco, L. P., \& Tee, M. Y. (2019). Social responsibility and engagement in higher education: Case of the ASEAN. International Journal of Educational Development, 66(August), 184-192. https://doi.org/10.1016/j.ijedudev.2018.10.001

UI. (2020). UI GreenMetric Work University Rangkings 2020. In Universitas Indonesia. https://doi.org/10.22487/j24775398.2016.v2.i2.6719

Universitas Muhammadiyah Surabaya. (2014). Standar Mutu Program Studi (berdasarkan indikator ban-pt). Accessed in August 2020 from https://ppm.um.surabaya.ac.id

Vaughn, P., \& Turner, C. (2016). Decoding via Coding: Analyzing Qualitative Text Data Through Thematic Coding and Survey Methodologies Decoding via Coding: Analyzing Qualitative. Journal of Library Administration, 56(1), 41-51. https://doi.org/10.1080/01930826.2015.1105035

Wijaya, L. S., \& Krismiyati, K. (2016). Penyusunan Model Program Corporate Social Responsibility (CSR) di Perguruan Tinggi Kota Salatiga Dalam Upaya Meningkatkan Intake Perguruan Tinggi. Jurnal Ekonomi Dan Bisnis, 17(3), 141-154. https://doi.org/10.24914/jeb.v17i3.311

Yulianita, N. (2008). Corporate Social Responsibility (CSR) sebagai Aktivitas Social Marketing Public Relations. Mediator: Jurnal Komunikasi, 9(1), 123-134. https://doi.org/10.29313/-mediator.v9i1.1145

Zangoueinezhad, A., \& Moshabaki, A. (2011). Measuring university performance using a knowledge-based balanced scorecard. International Journal of Productivity and 
Performance Management, 60(8), 824-843. https://doi.org/10.1108/17410401111182215

\section{Appendix}

\section{Interview Guideline}

The researchers prepared five main questions which were further broken down into subquestions, as follows:

1. Should social and environmental aspects be considered for organizations such as universities in assessing their performance? Why? (a) If the answer is yes, then have these social and environmental aspects been included in one of the indicators assessed by BAN-PT?; (b) If the answer is no, are there other more urgent aspects to consider in higher education performance? (If the answer is yes to (b), then under what criteria or rules is it regulated?

2. According to you, what are the elements or activities related to social aspects that can be carried out by tertiary institutions? Has the college done it? Why?

3. According to you, what are the elements or activities related to the environment that can be carried out by tertiary institutions? Has the university conduted it? Why?

4. According you, how can the forms of activities related to social and environmental aspects be accounted for and reported by universities? What is the accountability that you know so far?

5. According to you, is it appropriate for social and environmental aspects to be added in one of the criteria for BAN-PT? Or could it be a new criterion? Is the college ready to adopt it? 